\title{
VALLENS ÖVERVINTRING I NORRA FINLAND
}

\author{
E. A. Jamalainen \\ Forskningsanstalten för växtsjukdomar, Lantbrukets forskningscentral, Dickursby
}

Mottaget 10. 11. 1969

På det Nordkalottmöte, som i augusti 1969 hölls i Sverige, behandlades bl.a. frågan om vallens övervintring i norra Skandinavien. Följande framställning, delvis kompletterad, grundar sig på författarens föredrag på mötet i Sollefteå den 14. augusti.

\section{Vallgräsens övervintring $i$ södra och mellersta Finland}

På basen av undersökningar och försök utförda vid växtförädlingsanstalterna ${ }^{1}$ ), på Lantbrukets forskningscentrals försöksstationer samt vid Forskningsanstalten för växtsjukdomar $\left.^{2}\right)$ kan konstateras, att inga större skador förorsakade av utvintringssvampar i regel uppträder på de i södra och mellersta Finland allmänt odlade vallgräsen. Vissa år kan dock Fusarium nivale (Fr.) Ces., Typhula ishikariensis Imai och $T$. incarnata Lasch ex Fr. uppträda som skadegörare även på vallarna i landets södra delar. Tidvis förorsakar Sclerotinia borealis Bub. \& Vleugel skador på vallgräsen i mellersta Finland.

Nordiska sorter av timotej (Phleum pratense), ängssvingel (Festuca pratensis) och ängsgröe (Poa pratensis) uppvisar i södra och mellersta Finland, ävensom annorstädes i Skandinavien med motsvarande klimatförhållanden, en hög resistens mot utvintringssvampar. Hundäxing (Dactylis glomerata) är mottagligare för svampangrepp än ovan nämnda, likaså engelskt rajgräs (Lolium perenne) även i sydligaste Finland. Det är främst av denna orsak som sistnämnda art inte odlas i större utsträckning, fastän sorter såsom Valinge och vissa danska äger en resistens mot utvintringssvampar, som möjliggör odling i de södra delarna av landet.

1) Årsberättelser och försöksresultat från Växtförädlingsanstalten i Jokioinen (Jockis) samt försöksgårdarna Tammisto och Anttila vid Hankkijas växtförädlingsanstalt. Artiklar i Hankkijas växtförädlingsanstalts fröpublikation "Siemenjulkaisu».

$\left.{ }^{2}\right)$ Jamalainen, E. A. 1951. Förekomsten av övervintringssvampar på vallgräsen i Finland. Nord. jordbr.forsk., häfte 2-3: 529-534.

Jamalainen, E. A. 1961. Low-temperature parasitic fungi of grassland and their chemical control in Finland. Proc. 8th Intern. Grassland Congr. in England 1960: 194-196. 


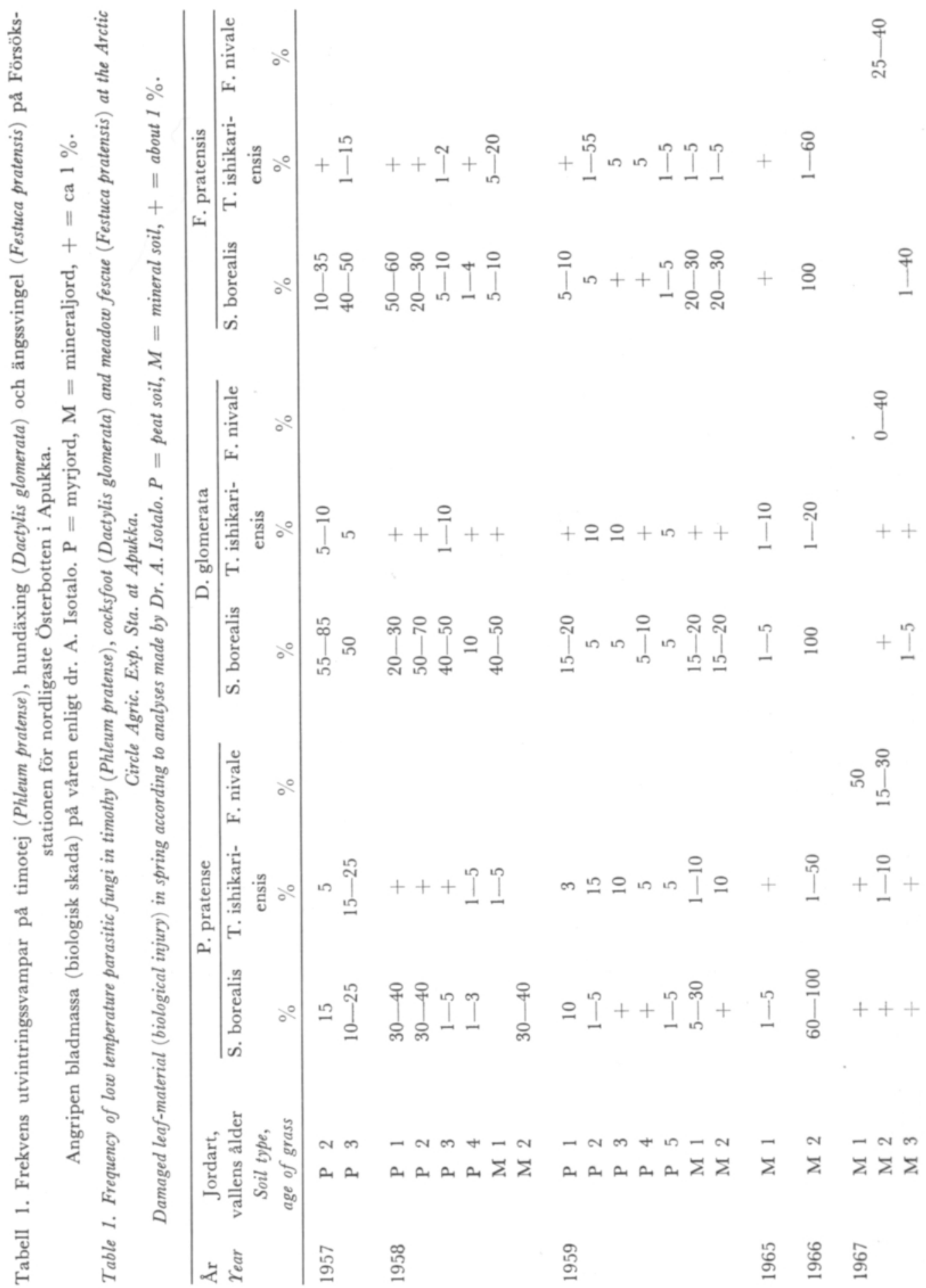




\section{Övervintringsskador på vallgräs $i$ norra Finland}

Värdefulla uppgifter om vallgräsens övervintring i norra Finland har erhållits från Försöksstationen för nordligaste Österbotten i Apukka utanför Rovaniemi, där stationens föreståndare dr. A. Isotalo under ett flertal år på våren noterat svampskadorna i vallgräsförsök på såväl kärr- som mineraljordar $\left.{ }^{1}\right)$. Tabell 1 visar skador av $F$. nivale, $S$. borealis och $T$. ishikariensis på bladmassan av timotej, ängssvingel och hundäxing enligt visuella analyser. Bestånden återhämtar sig vanligen till stor del under växtperioden, och de ekonomiska förlusterna blir därför mindre än vad våranalyserna utvisar.

Uppgifter om vallgräsens övervintring i norra Finland har även erhållits under de resor, som forskare vid Forskningsanstalten för växtsjukdomar på våren företagit till olika delar av Lappland, likaså från de övervintringsförsök, som anstalten där anordnat.

Skadegörelsen av $S$. borealis har varierat i hög grad under olika övervintringsperioder ${ }^{2}$ ). Det har funnits år, då svampen uppträtt synnerligen sparsamt, ävensom perioder med omfattande skador på timotej. Övervintringsperioden 1960-61 förorsakade $S$. borealis stor utgång av vallarna i norr (fig. 1), och 1965 - 66 var skadegörelsen på åtminstone timotej av samma storleksordning. På försöksstationen i Apukka förorsakade svampen våren 1966 nästan total utgång av bestånden i jämförande sortförsök med vallgräs (fig. 1). Det kan nämnas, att $S$. borealis ännu för några år sedan var rätt okänd bland befolkningen i norr, och att renarna ansågs skyldiga till de skador, som svampen förorsakade på övervintrande vallar. Av denna orsak fick renbeteslagen årligen betala ersättning åt jordbrukarna.
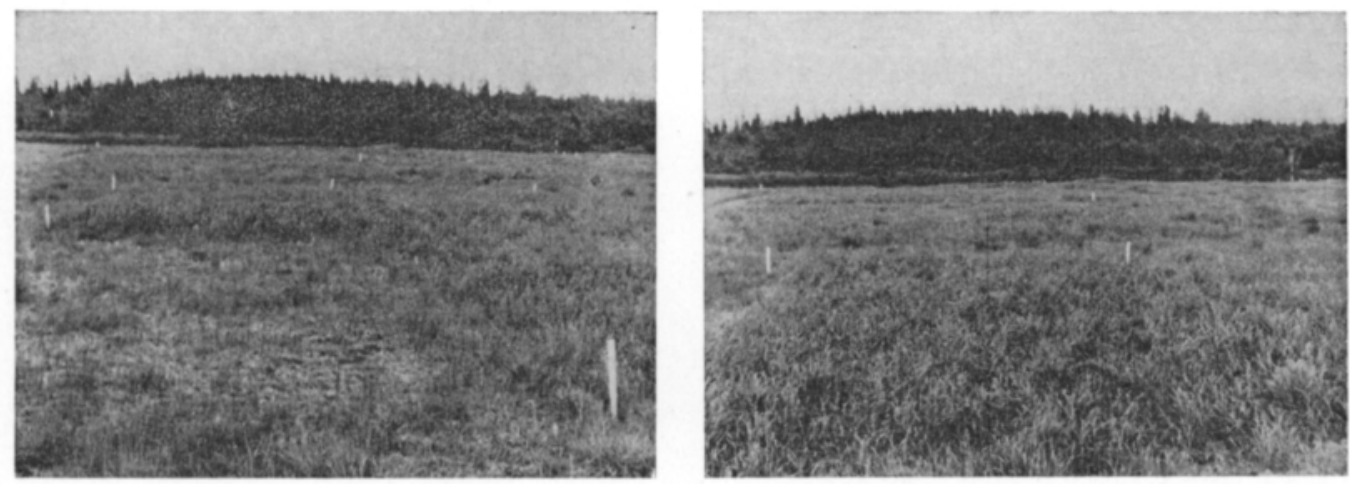

Bild 1. Tredje årets timotej på myrjord i kvävegödslingsförsök på Försöksstationen för nordligaste Österbotten i Apukka i början av juni 1961. Till vänster 0-ruta, där Sclerotinia borealis förstört beståndet; till höger försöksruta som erhållit $800 \mathrm{~kg} / \mathrm{ha}$ Ule-salpeter (N $26 \%$ ).

Fig. 1. Nitrogen-fertiliser experiment on third year timothy stand, on peat soil at the Arctic Circle Agric. Exp. Sta. at Apukka, early June 1961. On the right, plot 0 in which Sclerotinia borealis had destroyed the stand; on the left, plot which had received $800 \mathrm{~kg} / \mathrm{ha}$ Oulu salpetre $(\mathcal{N} 26 \%)$.

1) Årsberättelser och försöksresultat från Försöksstationen för nordligaste Österbotten.

${ }^{2}$ ) Jamalarnen, E. A. 1967. Nordisk gräsröta (Sclerotinia borealis) - en farlig sjukdom på vallgräs i norra Finland. På finska med svenskt och engelskt referat. Maatal. ja Koetoim. 21: 140-147. 
$S$. borealis är en boreal art och acklimatiserad till låga temperaturer. Enligt utförda försök är myceltillväxten hos svampen relativt snabb vid $0 \ldots+5^{\circ} \mathrm{C}$, svag däremot vid $+15^{\circ}$ C. $S$. borealis förorsakar de största skadorna då hösten är fuktig och kylig, snötäcket tjockt och jorden svagt tjälbunden samt då snön smälter långsamt på våren. Under en resa från Rovaniemi till Sodankylä via Muonio och Kittilä våren 1967 konstaterades, att vallarna övervintrat bättre än väntat trots en lång och snörik vinter. På en timotejvall i Kittilä var dock skadegörelsen av $S$. borealis $50 \%$.

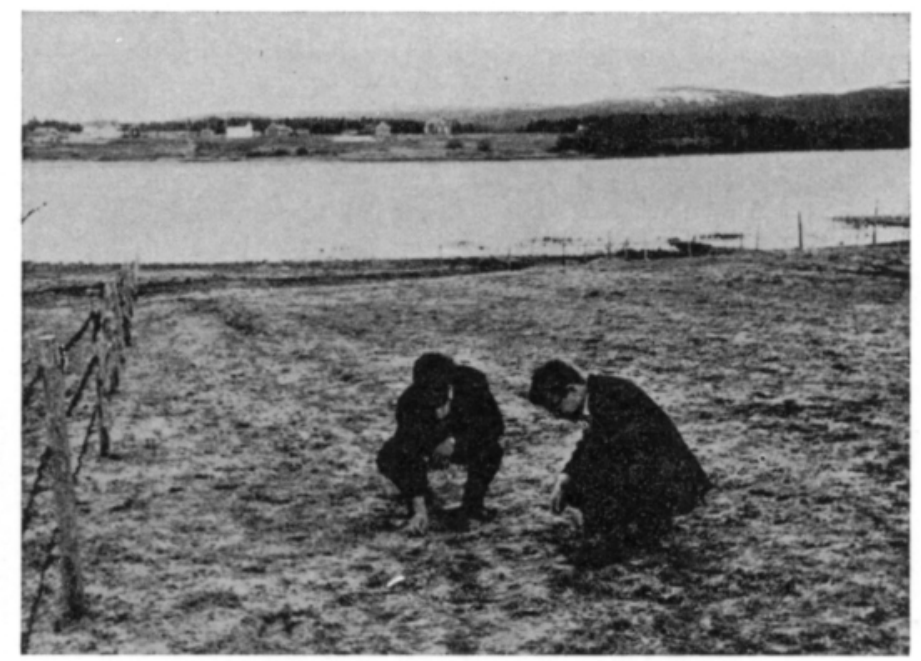

Bild 2. Skador av Typhula ishikariensis på första årets timotej i Lappland, Ivalo, Akujärvi. — Foto P. Talvia, 2. 6. 1969.

Fig. 2. Damage of Typhula ishikariensis in 1st-year timothy in Lapland, Ivalo, Akujärvi. - Photo P. Talvia, 2. 6. 1969.

Resan till Lappland våren 1969 omfattade besök på följande orter: Rovaniemi, Sodankylä, Ivalo, Enare, Utsjoki, Enontekiö, Muonio och Kittilä. Skadorna av övervintringssvampar var på vallarna mycket stora, och ca $50 \%$ av första årets timotej hade gått ut. Äldre vallar hade motstått svampangreppen bättre. Övervintringsperioden 1968-69 var $T$. ishikariensis den viktigaste skadegöraren i södra och mellersta Lappland (fig. 2). Längst i norr uppträdde däremot $F$. nivale med den högsta frekvensen. Nämnda period förorsakade $S$. borealis endast lokala skador. Uppskattningsvis $50 \%$ av skadorna på vallarna hade förorsakats av $T$. ishikariensis, återstoden av $F$. nivale och $S$. borealis. På första årets timotejvallar steg skadorna av $T$. ishikariensis i flera fall till $60-70 \%$. I Enare konstaterades $\mathrm{i}$ en första årets betesvall $50-60 \%$ skador av $S$. borealis.

Omfattande vattenskador kan vissa år uppträda i norra Finland på vallar belägna på kärrjordar. I samnordiska övervintringsförsök med förädlingar av vallgräs på försöksstationen i Apukka var vattenskadorna på kärrjord våren 1967 så omfattande, att försöken delvis förstördes. På grund av det tidiga och sent smältande snötäckets skyddande verkan 
förekommer inga regelbundna köldskador i norr. Om bestånden sent på hösten eller tidigt på våren ligger bara kan denna typ av skador dock bli betydande.

\section{Vallgräsförädlingarnas resistens mot utvintringssvampar $i$ norra Finland}

Enligt sortförsök på Försöksstationen för nordligaste Österbotten i Apukka kan lämnas följande uppgifter angående skador av utvintringssvampar på arter och förädlingar av vallgräs i norra Finland.

Av t i m o t e j s o r t e r n a har Tammisto, Tarmo, Phl. 78 samt vissa lokala stammar genomgått de flesta prövningarna. Av utländska sorter har i försöken ingått bl.a. Engmo (Norge), Bottnia II (Sverige), Climax (Kanada) och Lischover (Tyskland). Skadorna av utvintringssvampar har varierat under olika år samt i vallar av olika ålder. $S$. borealis var mycket skadlig 1965-66, då timotejmaterialet nästan helt förstördes. Vissa år har även angreppen av $T$. ishikariensis varit betydande. Första årets timotej har visat sig vara mest mottaglig för angrepp av utvintringssvampar. I försöken har inga större olikheter mellan de nordiska sorterna kunnat påvisas, utan under svåra svampår har samtliga angripts i ungefär samma utsträckning. Det nordiska timotejmaterialet har dock uppvisat den högsta resistensen mot utvintringssvampar. Av prövade utländska sorter har Lischover samt de kanadensiska varit mest mottagliga för angrepp.

På äng s svinge 1 har svampskadorna i Apukka varit av samma omfattning som på timotej. Försöken har omfattat de finska sorterna Tammisto och Paavo, den danska Hinderupgård samt den tyska Lischover.

I Apukka har $S$. borealis förorsakat större skador på h u n d ä x in g än $T$. ishikariensis. Angreppen har även varit kraftigare än på timotej. Försöken har omfattat sorterna Tammisto och Jo D $70 \mathrm{~A}$ från Finland, de danska Daeno II och Daehnfeldt, den tyska Lischover samt de amerikanska Masshardy och Pennlate.

Följande sorter av eng. $\mathrm{rajgras}$ har prövats på försöksstationen i Apukka: Daeno III och Hunsballe från Danmark, Valinge från Sverige samt tyska Lembker. Samtliga har varit mycket mottagliga för angrepp av $S$. borealis, och bestånden har flera år helt gått ut.

Ơvervintringsförsöken med vallgräs i Apukka har även omfattat rödsvingel (Festuca rubra), ängsgröe (Poa pratensis), ängskavle (Alopecurus pratensis), rörflen (Phalaris arundinacea) och foderlosta (Bromus inermis). Ängskavle har uppvisat en mycket hög resistens mot utvintringssvampar, medan rödsvingel och foderlosta starkt angripits av parasiterna.

Samnordiska övervintringsförsök med förädlingsmaterial av vallg räs. Försök för att klarlägga det nordiska förädlingsmaterialets av vallgräs resistens mot utvintringssvampar påbörjades 1966 på Försöksstationen för nordligaste Ósterbotten i Apukka (fig. 3), och följande år även på Mellersta Finlands försöksstation i Kuusa. För genomförande av detta samnordiska projekt har medel erhållits från statliga vetenskapliga kommisioner i Danmark, Finland, Norge och Sverige. I försöken har en $3 \mathrm{~m}$ bred kant av rutorna på senhösten behandlats med $50 \%$ PCNB (kvintozen), $10 \mathrm{~kg} / \mathrm{ha}$, vilket underlättat värderingen av såväl biotiska som abiotiska övervintringsskador.

I dessa försök uppträdde våren 1968 omfattande skador av $S$. borealis på timotej och ängssvingel (tab. 2). Óvervintringsperioden 1968-69 förstörde $T$. ishikariensis samtliga under prövning varande timotej- och ängssvingelförädlingar. 
$S$. borealis förorsakade 1967-68 stora skador på hundäxing (tab. 2). Effekten av sen hösten 1967 utförd PCNB-behandling förblev svag. I bestånden konstaterades även bety-
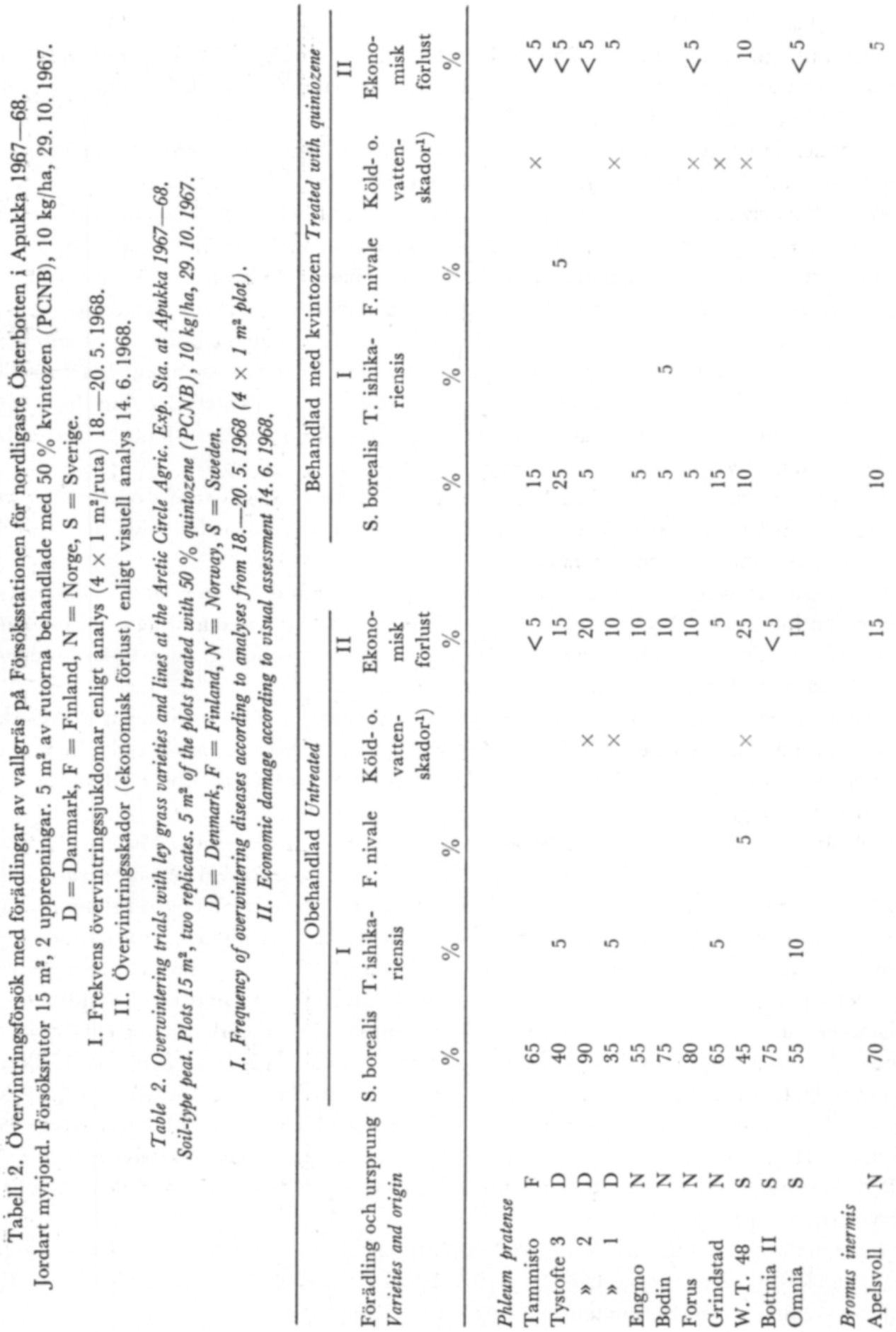
dande köldskador. 1968 - 69 gick samtliga hundäxingsorter ut till följd av angrep av T. ishikariensis.

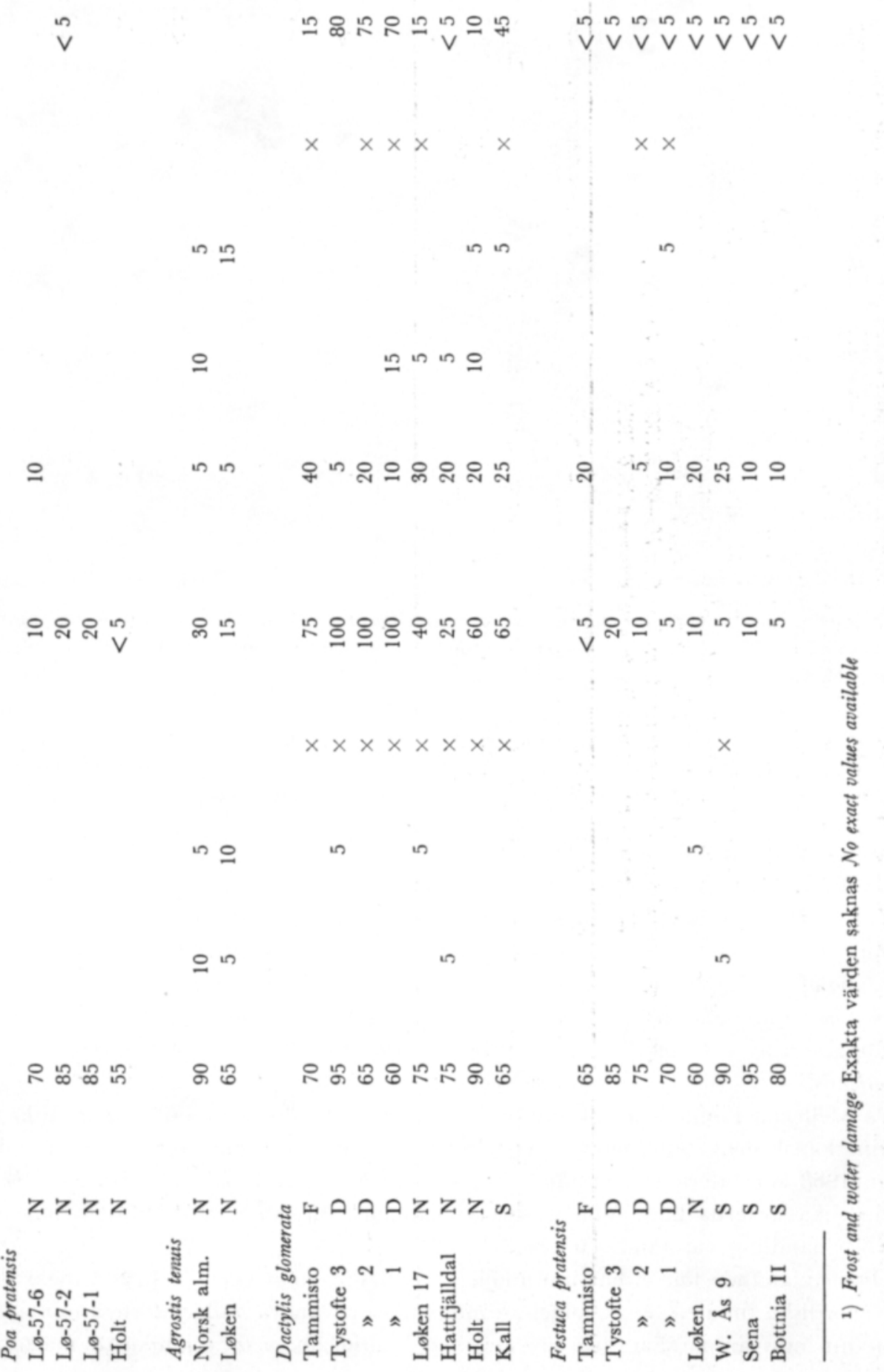




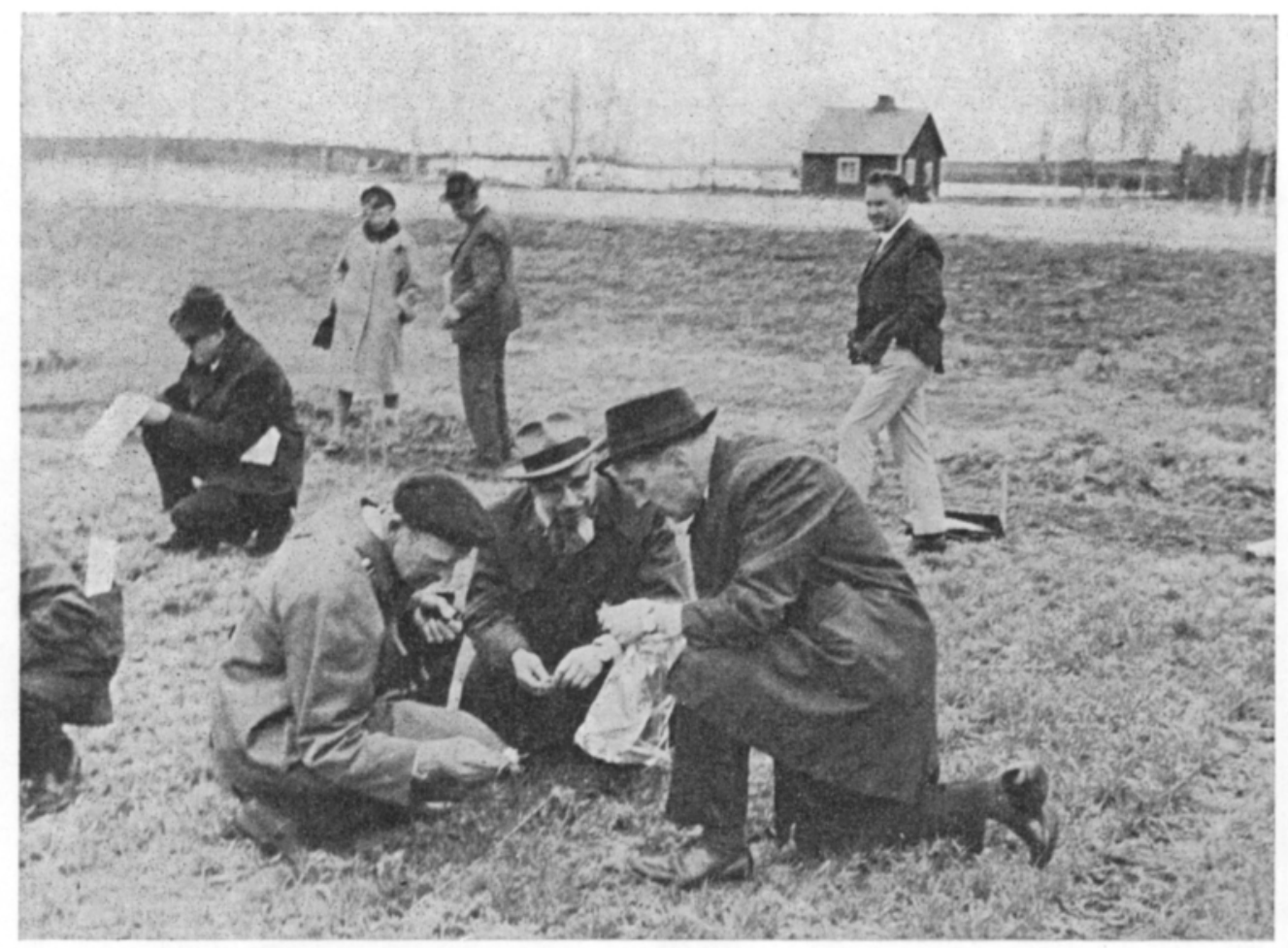

Bild 3. Medlemmar i NJF:s arbetsgrupp för övervintringsproblem på Försöksstationen för nordligaste Österbotten i Apukka 24. 5. 1967. I förgrunden från vänster till höger agr. lic. H. Hellqvist, Sverige, statsmykolog H. Roed, Norge, och fil. lic. N-O. Johansson, Sverige. Stående till höger försöksstationens chef dr. A. Isotalo.

Fig. 3. Members of overvintering working group of the Northern Countries Agricultural Scientists Society, at the Arctic Circle Agric. Exp. Sta. at Apukka, 24. 5. 1967. From left, Agr. Lic. H. Hellqvist from Sweden, State Mycologist H. Roed from Norway and Fil. Lic. N-O. Johansson from Sweden. Standing on the right director of the Exp. Sta. Dr. A. Isotalo.

Ovvervintringsperioden 1967—68 ingick i försöken fyra norska förädlingar av ängsgröe (Poa pratensis). Tre av dessa var starkt angripna av $S$. borealis, medan sorten Holt övervintrade bättre (tab. 2). De två prövade förädlingarna av rödven (Agrostis tenuis) var mottagliga för svampen. 1968 - 69 förtörde T. ishikariensis även det under prövning varande materialet av ängsgröe och rödven. Resultaten är såtillvida anmärkningsvärda att varken förädlingarna av timotej eller andra prövade vallgräs uppvisade någon resistens mot $T$. ishikariensis.

På Mellersta Finlands försöksstation i Kuusa anordnades 1967-68 samnordiska övervintringsförsök med förädlingar av engelskt rajgräs på såväl mo- som mjäljord (tab. 3). Våren 1968 konstaterades i bestånden skador av $F$. nivale, $T$. ishikariensis och $S$. borealis. Av de olika sorterna hade Valinge övervintrat bäst. Effekten av en hösten 1967 utförd PCNB-behandling var tämligen svag.

Ovan relaterade försök har inte möjliggjort några långt gående slutledningar beträffande nordiska timotej-, ängssvingel-, hundäxing- och andra vallgrässorters mottaglighet för utvintringssvampar. Samtliga har angripits kraftigt under för svamparnas massuppträ- 
dande gynnsamma övervintringsperioder. Forskningsanstalten för växtsjukdomar kommer i mån av möjlighet att fortsätta övervintringsförsöken med nordiskt förädlingsmaterial av

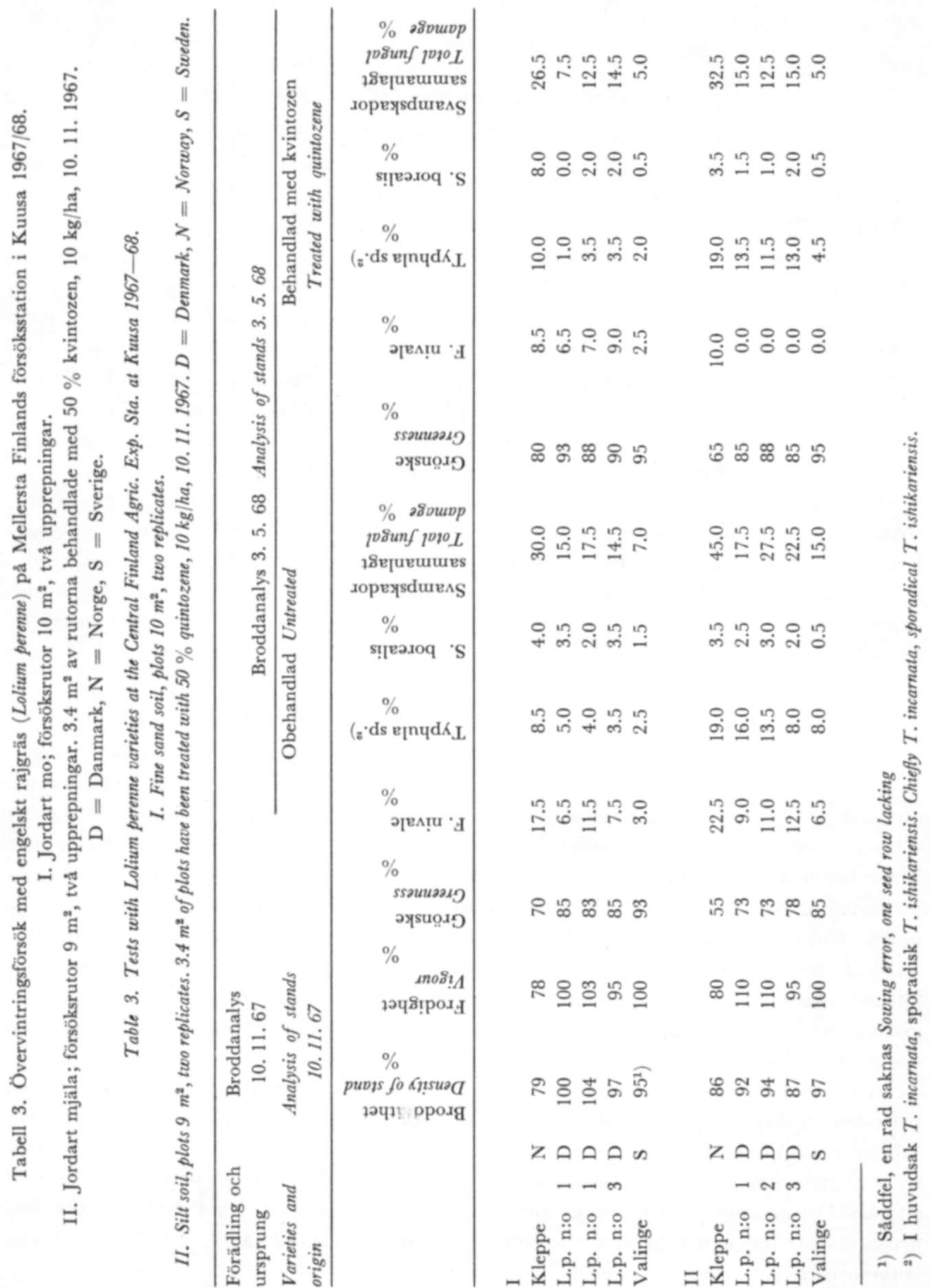


vallgräs på försöksstationerna i Apukka och Kuusa. I mindre skala kommer motsvarande försök även att ordnas på andra orter i norra Finland. Förädlingsmaterialets av vallgräs resistens mot olika utvintringssvampar skall likaså prövas i kontrollerade laboratorieförsök och i s.k. ramförsök i fält.

\section{Bekämpning av utvintringssvampar med PCNB-(kvintozen-)preparat}

På Försöksstationen för nordligaste Österbotten i Apukka har med timotej och ängssvingel anordnats övervintringsförsök, där bestånden på senhösten behandlats med PCNBpreparat $(50 \%, 10 \mathrm{~kg} / \mathrm{ha})$ mot angrepp av utvintringssvampar. Resultaten har i flera fall varit tillfredsställande. Övervintringsperioden 1967-68 anordnades behandlingsförsök även på ett flertal andra orter i Lappland (mag. P. Talvia). I Sodankylä konstaterades på obehandlad första årets timotej $20-30 \%$ skador av $F$. nivale och Typhula spp., $\mathrm{i}$ viss mån även av $S$. borealis. PCNB-behandlingen reducerade svampskadorna till ca $10 \%$. Verkan av PCNB var också god på första årets timotej i ett försök i Enontekiö. Kontrollrutorna uppvisade $25 \%$ skador av främst $F$. nivale, men även av $T$. ishikariensis. I ett annat försök på samma ort steg svampskadorna till ca $80 \%$ enligt följande: $T$. ishikariensis $40 \%$, F. nivale $20 \%$ och $S$. borealis $20 \%$. Effekten av PCNB var mycket god i försöket; de behandlade ytorna uppvisade endast små infektionshärdar av Typhula.

I de samnordiska vallgräsförsöken i Apukka behandlades hösten 1967 delar av försöksrutorna med PCNB-sprutmedel. Resultaten (tab. 2) visar, att effekten mot $S$. borealis i flera fall var mycket god. Behandlingen skyddade dock inte tillräckligt de sorter, som uppvisade en hög frekvens av svampen. Den svagaste effekten hade preparatet på hundäxingsorterna. I dessa försök konstaterades under följande år en gynnsam efterverkan av PCNB-behandlingen.

\section{Kvävets betydelse för vallgräsens övervintring}

Lantbrukets forskningscentrals arbetsprogram upptar sedan 1967 frågan om kvävets betydelse för en ökad äggvitehalt i vallgräsfoder. För ändamålet har försök med timotej, ängssvingel och hundäxing anordnats på forskningsanstaltens avdelningar och lokala försöksstationer på olika håll i landet. Doseringen har varit 150, 300, 450 och $600 \mathrm{~kg}$ rent kväve per hektar i form av Ule-salpeter (26\% N). Man kunde vänta sig, att stora kvävegivor skulle ha ökat skadegörelsen av främst $F$. nivale. Ett dylikt förhållande har dock inte i nämnvärd utsträckning kunnat påvisas. Intressanta var kvävegödslingsförsöken i Apukka perioden 1967 - 68. I de timotejrutor som inte erhållit kväve uppträdde omfattande skador av $S$. borealis. Däremot hade inte de bestånd, som erhållit stora kvävegivor angripits av svampen. I detta fall ökade kvävet motståndskraften hos timotej mot angrepp av $S$. borealis (jfr fig. 1).

$\AA$ andra sidan var stora kvävegivor ur övervintringssynpunkt skadliga i vissa försök perioden 1968 - 69. På Tavastlands försöksstation i Pälkäne, Karelens försöksstation i Anjala samt på Växtodlingsanstalten i Dickursby ledde stora kvävegivor till utgång av timotej och ängssvingel (fig. 4). I dessa fall kunde på våren inga skador av utvintringssvampar påvisas. Det är sannolikt att växter som erhållit stora mängder kväve förlorar socker med nedsatt vinterhärdighet som följd, fastän även andra okända faktorer i detta fall kan komma i fråga. 


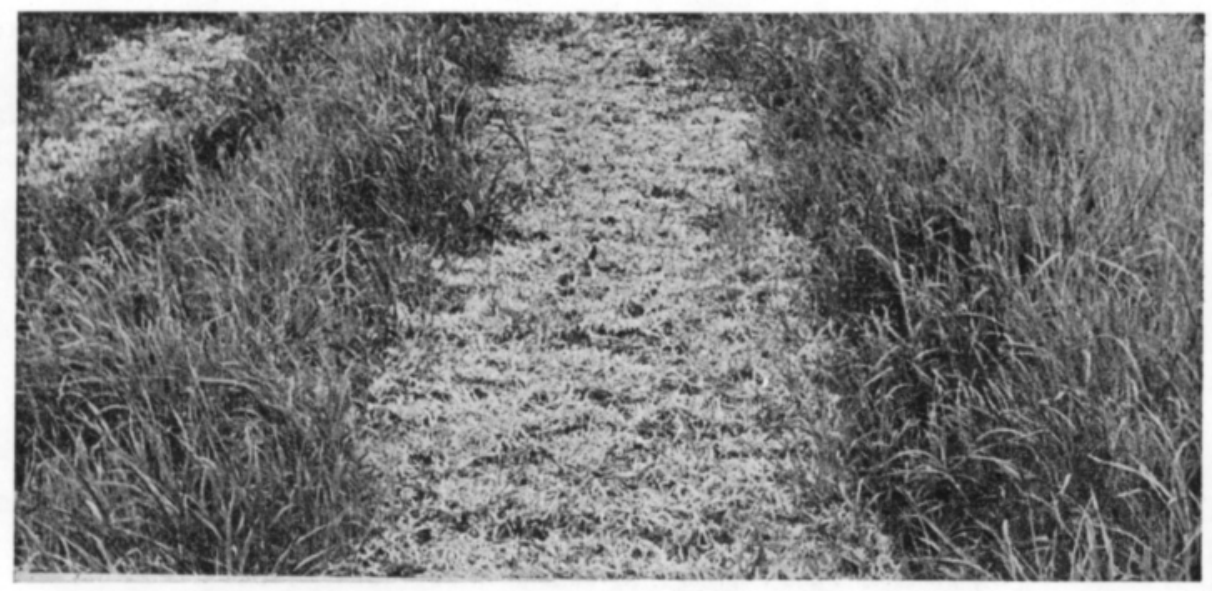

Bild 4. Ängssvigelförsök med stigande mängder kväve på Tavastlands försöksstation i Pälkäne 7. 6. 1969. Försöksrutan till vänster har erhâllit $450 \mathrm{~kg} / \mathrm{ha}$ rent kväve i form av Ule-salpeter, härefter 0-ruta, ruta erhållit $600 \mathrm{~kg} / \mathrm{ha}$, där beståndet gick ut under vintern, och längst till höger en annan 0-ruta.

Fig. 4. Meadow fescue trial at the Häme Agric. Exp. Sta. at Pälkäne, with increasing applications of nitrogen Oulu salpetre. Photo taken 7.6.1969. On the left, plot receiving $450 \mathrm{~N} \mathrm{~kg} /$ ha, next, plot without salpetre, the following plot, 600 $\mathcal{N} \mathrm{kg} / \mathrm{ha}$, where the stand disappeared during the winter, on the right a plot without salpetre.

\section{Slutledning}

Vid odling av vallväxter inom Nordkalottområdet är skador förorsakade av utvintringssvampar av stor betydelse. Omfattande svampskador är dock ingen regelbunden varje år återkommande företeelse, men under gynnsamma betingelser kan Sclerotinia borealis, Typhula ishikariensis och delvis även Fusarium nivale förorsaka t.o.m. total utgång av övervintrande vallar. Vissa år har $S$. borealis förorsakat de största skadorna, andra $T$. ishikariensis. Utvintringssvamparna är således faktorer, som genom ett oväntat massuppträdande inger osäkerhet vid odling av vallväxter under nordliga förhållanden. På vallarna i norr kan även uppträda köld- och vattenskador, de sistnämnda isynnerhet på kärrjordar.

Det förädlingsmaterial av vallgräs, som nu odlas inom Nordkalottområdet, är beträffande resistensen mot utvintringssvampar det härdigaste som står att få. Också detta material är emellertid mottagligt för angrepp under för svamparnas massuppträdande gynnsamma betingelser, och det krävs helt säkert dryga arbetsinsatser av växtförädlarna för att kunna höja resistensen mot nämnda patogener.

För att reducera skadorna förorsakade av utvintringssvampar bör endast de mest motståndskraftigaste, till rådande nordliga förhållanden acklimatiserade förädlingarna odlas. Det kan antas, att en riklig, väl avvägd P-, K- och N-gödsling stärker växterna inför övervintringsperioden.

Genom fungicidbehandling av bestånden på senhösten med främst PCNB-(kvintozen-) preparat kan övervintringen i stor utsträckning säkras. Behandlingens lönsamhet ökar genom preparatets efterverkan under andra och tredje året. Vid massuppträdande av utvintringssvampar har dock inte effekten hos $50 \% \mathrm{PCNB}, 10 \mathrm{~kg} / \mathrm{ha}$, varit tillräcklig, och i detta fall borde större mängder användas. 
På forskningsanstaltens för växtsjukdomar vägnar önskar jag tacka chefen för Försöksstationen för nordligaste Österbotten, dr. A. Isotalo, för värdefulla uppgifter om vallväxternas övervintring i norra Finland samt mag. H. Blomqvist och mag. P. Talvia för den information, som dessa insamlat under sina resor i norra Finland, och som välvilligt ställts till mitt förfogande.

\section{SUMMARY}

\section{OVERWINTERING OF LEY GRASSES IN NORTH FINLAND}

\section{E. A. Jamalainen}

\section{Department of Plant Pathology, Agricultural Research Centre, Tikkurila}

This discussion, with some additions by way of completion, is based upon a paper read by the author in Sollefteå, Sweden, Aug. 14th 1969, where Norwegian, Swedish and Finnish experts discussed some problems relating to agriculture in North Scandinavia.

On the basis of research and experiments carried out at plant breeding institutes, local agricultural experimental stations and the Department of Plant Pathology, it has been possible to establish that extensive damage due to low temperature parasitic fungi is not encountered regularly in South or Central Finland. In certain years, however, Fusarium nivale (Fr.) Ces., Typhula ishikariensis Imai (syn. T. idahoensis Remsb.) and $T$. incarnata Lasch ex Fr. may appear as a cause of injury, even in the Southern parts of the country. Sclerotinia borealis Bub. \& Vleugel occasionally causes losses in Central Finland.

In Central and South Finland the Scandinavian varieties of timothy (Phleum pratense), meadow fescue (Festuca pratensis) and meadow grass (Poa pratensis) are, as in corresponding conditions elsewhere in Scandinavia, comparatively resistant to low temperature parasitic fungi. Cocksfoot (Dactylis glomerata) is more susceptible to these fungi than the former grasses, as is perennial rye-grass (Lolium perenne) also in South Finland.

Overwintering damage to ley grasses in North Finland. Significant results on the overwintering of ley grasses in North Finland have been obtained at the Arctic Circle Agricultural Experimental Station at Apukka, near Rovaniemi. The director of this station, Dr. A. Isotalo, has during several successive springs carried out visual analyses of the damage caused by low temperature parasitic fungi in ley grass trials, which have been run on both peat bog and mineral soils. Table 1 presents data on the damage by $F$. nivale, $S$. borealis and $T$. ishikariensis to a plant stand of timothy, meadow fescue and cocksfoot, according to visual assessments. The plant stand usually recovers during the growing season, so that the economic losses are less than the spring assessments might indicate.

Information about the overwintering capacity of ley grasses in North Finland has also been obtained on journeys made from the Dept. of Plant Pathology into L.apland.

Damage caused by $S$. borealis varies greatly from winter to winter. There have been years in which the fungus has been comparatively rare, whereas in other years the damage caused to timothy and other ley grasses has been very extensi e. In the winter season 1960-61 S. borealis caused particularly severe injury in North Finland (cf. Fig. 1), and in the overwintering season 1965-66 the damage was on the same scale. In the spring of 1966, at the Arctic Circle Agric. Exp. Sta. at Apukka, this fungus caused almost complete failure in the comparative experiments between the different ley grasses. $S$. borealis is adapted to low-temperature conditions. In experiments made at the Dept. of Plant Pathology, the mycelia of this fungus grew relatively rapidly at $0 \ldots+5^{\circ} \mathrm{C}$, while at $+15^{\circ} \mathrm{C}$ their growth was weak. The fungus causes the greatest damage when the autumn is damp and chilly, the snow cover thick and the ground only slightly frozen, and also in the spring if the snow melts slowly.

During the spring of 1969, damage by low temperature parasitic fungi in Lapland was very extensive, about $50 \%$ of 1st-year timothy being destroyed in several districts. Older stands of the grass had escaped fungal injury to a greater degree. In the overwintering season $1968-69, T$. ishikariensis was the chief cause 
of damage in South and Central Lapland (Fig. 2). Further north, $F$, nivale replaced it with increasing freguency. During this season $S$. borealis caused only local damage.

Extensive damage by low temperature parasitic fungi does not in fact occur year by year in North Finland, but in winters that are favourable for the fungi, $S$. borealis and $T$. ishikariensis, and in part also $F$. nivale, may cause even total losses of the leys. In some years $S$. borealis, in others $T$. ishikariensis, are the causes of the largest amounts of damage. Under these circumstances, low temperature parasitic fungi are factors which, when they appear, make the cultivation of ley grasses uncertain under northern conditions.

In certain years water injuries may occur on grasses grown on peat soils in North Finland. As the snow-cover is formed early and melts late, greater injury from frost does not generally occur in the north. If the ground is still bare late in the autumn or early in the spring, frost damage may appear.

Information concerning the resistance of ley grasses to low temperature parasitic fungi has been obtained at the Arctic Circle Agric. Exp. Sta. at Apukka, during trials of ley grass varieties carried out over a number of years. Mainly Finnish and Swedish varieties were used in these experiments. In addition, a few varieties from Denmark, Germany and Canada were tried.

Damage by low temperature parasitic fungi to timothy varied greatly from year to year, and depending on the age of the grass stands. First year leys proved to be the most susceptible to overwintering injury. Damage to varieties of meadow fescue by low temperature parasitic fungi was of the same order as to varieties of timothy. Overwintering damage to varieties of cocksfoot by these fungi was greater than to either timothy or meadow fescue. Varieties of perennial ryegrass were, practically speaking, incapable of overwintering at Apukka, on account of fungal damage.

Since the beginning of 1966, experiments have been carried out to study in Finland the resistance to low temperature parasitic fungi of the varieties and lines of ley grasses obtained from plant breeding institutes in other Scandinavian countries. The experiments were made at the Arctic Circle Agric. Exp. Sta. at Apukka (Fig. 3) and also later at the Central Finland Agric. Exp. Sta. at Kuusa. In order to realise this joint Scandinavian project, financial support has been provided by state scientific commissions from Denmark, Finland, Norway and Sweden.

A three metre wide border within the experimental plots was treated with $50 \%$ quintozene or PCNB (pentachloronitrobenzene), applied at the rate of $10 \mathrm{~kg} / \mathrm{ha}$ in late autumn. This measure facilitated the estimation of biotic and abiotic damage to the plant stands in the experiments.

In these trials, which had been made on peat soil, severe injury by water occurred during the winter season 1966- 67. In the spring of 1968, $S$. borealis appeared in great abundance and caused damage to timothy, meadow fescue and cocksfoot. In the winter season 1968-69, T. ishikariensis almost completely destroyed all the varieties and lines of grasses in the trials. In the trials run over the overwintering season 1967 - 68, the residual effect of the PCNB in cocksfoot was comparatively small. Considerable frost damage also occurred in this grass. Four Norwegian varieties and lines of meadow-grass were included in these trials. Three lines were badly damaged by $S$. borealis, as were two varieties of common bent-grass which were included in the trial (Table 2).

At the Central Finland Agric. Exp. Sta. at Kuusa, a joint Scandinavian overwintering experiment with perennial ryegrass was carried out on both fine sand and silt soil (Table 3). Damage by $F$. nivale, $T$. ishikariensis and $S$. borealis was found to have occurred within the plant stand. Among the various varieties used, the Swedish variety Valinge overwintered best. The residual effect of the PCNB application made in the autumn of 1967 was quite small.

On the basis of the experiments described above, it is not possible to draw any long-term conclusions regarding the relative susceptibilities to low temperature parasitic fungi of varieties of timothy, meadow fescue, cocksfoot, or other ley grasses. The varieties of ley grasses cultivated in North Finland at present are among the most resistant of all existing varieties to low temperature parasitic fungi. Nevertheless, even these varieties are very susceptible to attack when conditions are favourable for the appearance of the fungi. The plant breeder will certainly still be called upon to do a lot more work in breeding varieties more resistant to these parasites in northern part of Scandinavia than we have at present.

PCNB (quitozene) application to low temperature parasitic fungi. In the trials made at the Arctic Circle Agric. Exp. Sta. with timothy and meadow fescue, to stands of which PCNB preparation $(50 \%, 10 \mathrm{~kg} / \mathrm{ha})$ had been applied during the autumn before the snow came, the application gave satisfactory control of low temperature parasitic fungi in several cases. During 
the winter season $1967-68$, at several sites in Lapland, trials were made in which this substance was applied to plant stands. In several of these experiments, the use of PCNB gave excellent, or at least satisfactory control of low temperature parasitic fungi. The degree of effectiveness of PCNB in controlling $S$, borealis, on Scandinavian plant breeding material at Apukka 1967-68 (Table 2), was quite high in several cases. The application, however, was not sufficiently large to protect adequately those varieties which were particularly susceptible to these fungi. By means of an application of quintozene to first year grass leys, it was possible to establish that the residual effect in yield increases also during later years.

The significance of nitrogen in the overwintering of grasses. In 1967, the Agric. Res. Centre took up the study of the significance of nitrogen in increasing the protein content of ley grasses under cultivation. For this purpose, experiments were established with different ley grasses at the Dept. of Plant Husbandry, and at local experimental stations in various parts of the country. The nitrogen applications were $150,300,450$ and $600 \mathrm{~kg} / \mathrm{ha}$ of nitrogen in the form of nitrate (Oulu Saltptre, $26 \% \mathrm{~N}$ ). One might have expected that the abundant quantities of nitrogen would, have promoted damage by $F$. nivale. However, that this was not the case could be established with some degree of certainly. In the nitrogen fertilizer trials made at the Arctic Circle Agric. Exp. Sta. at Apukka during the winter season $1967-68$ and earlier (Fig. 1) extensive damage due to $S$. borealis appeared in timothy, in the plots to which no nitrogen had been applied. On the other hand, stands of timothy supplied with abundant quantities of nitrogen remained free of fungus damage. In this case, nitrogen increased the resistance of timothy to $S$. borealis.

As opposed to this, large applications of nitrogen were injurious as regards overwintering in the experiments made in 1968 - 69. At the Häme Agric. Exp. Sta. at Pälkäne in Central Finland (Fig. 4), the Karelia Agric. Exp. Sta. at Anjala East Finland, and at the Dept. of Plant Husbandry at Tikkurila, near Helsinki, large quantities of applied nitrogen resulted in complete or nearly complete destruction of timothy and meadow fescue. In these instances no evidence of damage by low temperature parasitic fungi was found. The stands which had received large amounts of nitrogen were destroyed. It is likely that plants which have received large quantities of nitrogen lose their reserves of sugar during the winter, resulting in a weakened overwintering capacity. Factors as yet unknown may also enter into the picture. 